\title{
Ecological Studies on Common Land Snail Species Infesting Guava and Navel Orange Orchards in Two Regions at Kafr El-Sheikh Governorate Alyaa A. Gazzy ${ }^{1}$; Nadia M. Mostafa ${ }^{2}$ and Wafaa A. Shahawey ${ }^{2}$ ${ }^{1}$ Zoology Department, Faculty of Science, Kafr EL- Sheikh University ${ }^{2}$ Plant Protection Research Institute, A.R.C
}

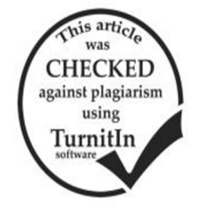
and Salait village, Quallen distrect at Kafr El- Sheikh Governorate during two successive seasons, 2015 - 2016 \& 2016 - 2017 in guava and navel orange orchards. Survey study revealed the existence of three species of land snails, Monacha cantiana, Cochlecilla acuta and Thiba pisana in both of two orchards in two studied regions. Also, survey showed that M. cantiana was predominant in orchards in two studied villages. The population density of these land snail species was studied on soil, stems and leaves of studied trees. The results showed that the highest population was recorded on the soil around trees during spring season. M. cantiana and C. acuta recorded highest population on guava trees, while $T$. pisana was recorded with highest numbers on navel orange in two studied regions during two seasons. Population dynamics of land snail species were recorded on guava and navel orange from sep. 2015 until Aug. 2017. The results showed that the maximum number of the three land snails M.cantiana, C.acutaand and T. pisan in the two orchards in sedy salm were (495.1) and (143.9) snails / tree during July and June and the lowest number were recorded (12.4) and (19.0) snail / tree during February and March in the first season 2015 /2016. The results also showed that the highest record was (87.9) and (226.0) snails/tree in guava and navel orange orchards during June and May, meanwhile the lowest records (32.7) \& (6.0)snails / tree during February and November, respectively in the second season $(2016$ - 2017). The results also showed that M.cantiana snail recorded the highest numbers on guava and navel orange orchards (260.2) (139.5) snails / tree, during April 2016 and (501.0)(180.4) snails / tree during April in the second season .Estimation of damage caused by $M$. cantiana land snails to the two orchards were 13,7 and $10.4 \%$ in orange and guava respectively.

Keywords: land snails, Monacha cantiana, Theba pisana and Cochlicella acut, Egology, guava and navel orange

\section{INTRODUCTION}

Molluscs is the third most important animal pest group after Arthropoda and Vertebrata. The land snails are considered as an extremely injurious pest to wide variety of fruits and citus in most areas of their distribution (Nadia and Refaei, 2018 ) They were known as destructive pests causing great damage to guava and navel orange trees (Mahrous et al. 2002, Ismail, et al. 2011). Land snails are common name of the numerous species that live on land, as opposed to those that live in shelters and fresh water. From the important species, the herbivorous land snail species which was found on different host trees and caused severe damage to all tree parts as a result of the mucus secretion and the particular structure of their mouth parts enabling scratching and crushing. From these species the land snail M. cantiana, C. Acuta and T. pisana which were found on most of fruit trees at Kafr El-Sheikh Governorate. The land snail M. Cantiana was most dominant species as it was collected from orchards of navel oranges and guava at Kafr El-Sheikh Governorate (Shahawy, 1998). Ecological conditions play the important role in the distribution and biology of these species. So, the present work was directed to study ecological factors to design safety and successful programs to control these pests to avoid environmental pollution. In addition to estimation the damage in two studied orchards (guava and navel orange) which was caused by these species.

\section{MATERIALS AND METHODS}

Ecological studies on different land snail species at Kafr El-Sheikh Governorate

1-Survey:

These studies on different land snail species were conducted under field conditions at $\mathrm{Abu}$-Abdalla village, Sedy salem district and Salait village, Quallen district at Kafr El-Sheikh Governorate. In this respect, guava (Pesidium guava) and navel orange (Citrus sinesis) as a horticulture crops were chosen to study which was infested by different land snail species. Monthly survey at period from September 2015 to August 2017 during two successive seasons were carried out. In each district, one feddan from each of guava and navel orange species was randomly chosen and 5\% wetted bran baits were used as attractive bait and distributied beside and under trees before sun set as a land trap. The snails were collected and transported to laboratory in white close bags to identified according to Godan (1983).

2- Population dynamics:

Survey studies of land snail species during period from September 2015 to August 2017 showed three different species of snails were found at previous sites. These species were $M$. cantiana, C. acuta and T. pisana . Population density of snail species were monthly recorded on guava and navel orange trees of each region from September 2015 to August 2017. Individuals of each land snail species were counted from all parts of the tree and the soil surrounded them.

\section{3- Damage estimation}

Damage caused by snails to guava and orange leaves, were estimated under field conditions during spring season $2016-2017$.

To estimate leaves damage caused by snails, the experiment was carried out at Abu -Abdalla village, Sedy Salem district, in one feddan was cultivated with each of guava and orange trees. Ten trees of each were chosen. Each tree was divided to three parts, top, middle and bottom. Thirty leave were collected from each part, whole leaf area and whole damaged area were estimated according to the equation by El-Deeb et al. ,1985.

Damage area $\%=$ Area of damage leaf surface $/$ whole area of leaf x100

\section{RESULTS AND DISCUSSTION}

\section{1- Ecological studies on different land snail species at} Kafr El- Sheikh Governorate

1- Survey:

Although terrestrial Molluscas (slugs and snails) seem poorly suited by their biology to become pests, they 
frequently cause problems. Land snail species infested two orchards of guava and navel orange at Abu-Abdalla village, Sedy salem district and Salait village, Quallen district at Kafr El-Sheikh Governorate.

Data in Table (1) revealed the herbivorous land snail species which were found in two orchards guava and navel orange. These species were $M$. cantiana, $T$. pisana and $C$. acuta. These species varied in level of infestation according to each locality and host type. Generally, the listed hosts can be classified into three categories according to the degree of infestation. These were; heavy, moderate and light infestation.

The results showed that the examined guava orchards in the two localities were found with heavy infestation especially $M$. Cantiana and $C$. acuta and moderate infestation of $T$. pisana. Navel orange orchards were found with heavy infestation of $T$. pisana in two localities. In Abu- Abdalla and Saliat villages in citrus orchards there were moderate infestation and heavy infestation of $M$. Cantiana, respectively. C. acuta were counted with heavy and moderate infestation on navel orange in Abu- Abdella and Salait villages, respectively. Mohamed (1994) recorded Monacha obstructa on seedlings of citrus at cairo. Also, Shahawy (1998) recorded three species of herbivorous land snails on guava and navel orange at Kafr El-Sheikh Governorate. These species were the glassy clover snail $M$. Cantiana, the brown garden snail Eobania vermiculata and the conical snail, Cochlicella acuta. The snails E. vermiculata and $C$. acuta were recorded in very few numbers, while $M$. cantiana was the predominant species.

Table 1. Survey and distribution of terrestrial land snail species on navel orange and guava in two localities at Kafr El- Sheikh Governorate.

\begin{tabular}{lccc}
\hline Location & Snail species & \multicolumn{2}{c}{ Host plant } \\
\hline \multirow{4}{*}{$\begin{array}{l}\text { Abu-Abdalla } \\
\text { village }\end{array}$} & Monacha cantiana & $\begin{array}{c}\text { Citruc sinesis } \\
\text { Pesidium guava }\end{array}$ & $(+++)$ \\
\cline { 2 - 4 } Salait villag & Cochlecilla acuta & $\begin{array}{l}\text { Pesidium guava } \\
\text { Citruc sinesis }\end{array}$ & $(+++)$ \\
\cline { 2 - 4 } & Theba pisana & $\begin{array}{c}\text { Pesidium guava } \\
\text { Citruc sinesis }\end{array}$ & $(++)$ \\
\cline { 2 - 4 } & Monacha cantiana & $\begin{array}{c}\text { Citruc sinesis } \\
\text { Pesidium guava }\end{array}$ & $(+++)$ \\
\cline { 2 - 4 } & Cochlecilla acuta & $\begin{array}{c}\text { Citruc sinesis } \\
\text { Pesidium guava }\end{array}$ & $(++)$ \\
\cline { 2 - 4 } & Theba pisana & $\begin{array}{c}\text { Citruc sinesis } \\
\text { Pesidium guava }\end{array}$ & $(+++)$ \\
\hline
\end{tabular}

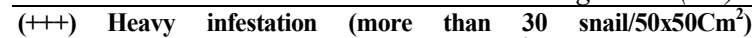
$(++)$ Moderate infestation (16-30 snail/50x50 $\left.\mathrm{Cm}^{2}\right)$

(+) Light infestation (1-15 snail/50x50 $\left.\mathrm{Cm}^{2}\right)$

\section{2- Population dinamics:}

Data in Table (2) showed that, the maximum population densities of snails on guava trees at Abu Abdalla village were (203.1), (251.0) and (41.0) individuals/tree for M. cantiana, C. acuta and T. Pisana, respectively in July 2016, while the minimum of $M$. cantiana values were (5.0), (16.1) and (5.6) individuals/tree during November, September and October $2015-2016$ season for the three snail species respectively. On orange trees, the maximum population densities were (70.0) individuals/tree for M.cantiana during April 2016, and each of C. acuta and T. pisana in June 2016, recorded (46.0) individuals/ tree, the same results were obtained by
Sharshir et al. (1996) who studied the population density of the land snail M. cantiana on navel orange, Egyptian clover, sugar beet and broad bean at Kafr El- Sheikh Governorate. The snail peak occurred in June on navel orange, while the minimum values were (4.5), (4.9) and (5.9) individuals/ tree during November 2015 for $M$. cantiana and for both of C. acuta and T. pisana in March 2016, respectively. Highest total number for three species was recorded 495.1in July 2016 on guava trees while it recorded 143.9 during June 2016 on orange trees.

Data in Table (3) revealed that $M$. cantiana, $C$. acuta and $T$. pisana species were recorded on guava and orange trees at Abu-Abdalla village, Sedy Salem district. Snails of the three species were recorded in different relative abundance in the whole year of second season 2016-2017. On guava trees, the peak of snail number was recorded during June (46.0), May (39.0) and July (11.0) individuals/tree for the three land snail species, respectively. Comparison between these land snail species on orange trees, the three snail species reached their maximum numbers during May (151.0) for M. cantiana, June $(34.0)$ for C. acuta and May $(45,0)$ for T.pisana individuals/tree.

The results disagree with Asran et al. (2011). He reported that the lowest infestation of land snails for navel orange during May 2009 and 2010. The results obtained that C. acuta occurred one peak in June 2017, on navel orange at the previous region in the second year. Navel orange recorded the highest amount of the three land snail species, the total number of snails were counted as 226.0 followed by guava 87.9 individuals/ tree during the whole year months. T. pisana was recorded on navel orange from March to November and from February to November at Abu Abdalla, Sedy Salem district, Kafr El- Sheikh Governorate during the first and second seasons, respectively. Hashem et al. (1993) recorded and monitored the snail population in the north Delta region, Behera Governorate on sweet orange trees during two successive years (1990 and 1991). He reported that snails were noticed on citrus trees from March to November for $T$. pisana and from March to October for C. acutta.

Table 2. Population dynamics of land snail species on guava and navel orange trees at Abu-Abdalla village, Sedy Salem district, Kafr El- Sheikh Governorate, 2015-2016 season.

\begin{tabular}{lcccccccc}
\hline & \multicolumn{6}{c}{ Average number of snail species } \\
\cline { 2 - 9 } Months & \multicolumn{6}{c}{ Guava } & \multicolumn{5}{c}{ Orange } \\
\cline { 2 - 9 } & M & C & T & Total & M & C & T & Total \\
\hline Sep. & 6.2 & 16.1 & 9.6 & 31.9 & 17.3 & 13.6 & 17.0 & 47.9 \\
Oct. & 6.0 & 39.1 & 5.6 & 50.7 & 9.5 & 29.0 & 14.0 & 42.5 \\
Nov. & 5.0 & 20.0 & 7.0 & 32.0 & 4.5 & 21.0 & 9.1 & 34.6 \\
Dec. & - & - & - & - & - & - & - & - \\
Jan. & - & - & - & - & - & - & - & - \\
Feb. & 6.4 & - & 6.0 & 12.4 & - & - & - & - \\
Mar. & 21.9 & 20.1 & 12.3 & 54.3 & 8.2 & 4.9 & 5.9 & 19.0 \\
Apr. & 16.2 & 121.0 & 36.1 & 173.3 & 70.0 & 16.2 & 22.0 & 108.2 \\
May & 120.0 & 159.0 & 38.0 & 317.0 & 42.6 & 23.0 & 27.0 & 93.6 \\
Jun. & 91.0 & 246.0 & 29.0 & 366.0 & 51.9 & 46.0 & 46.0 & 143.9 \\
JUL. & 203.1 & 251.0 & 41.0 & 495.1 & 62.0 & 40.0 & 24.0 & 126.0 \\
Aug. & 98 & 99.0 & 20.0 & 217.3 & 51.0 & 30.0 & 21.0 & 102.0 \\
\hline Total & 574.1 & 971.3 & 204.6 & 1549.0 & 337.0 & 223.7 & 186.0 & 746.0 \\
\hline Mean & 37.8 & 81.0 & 17.1 & 121.7 & 28.1 & 18.6 & 15.6 & 62.2 \\
\hline M.
\end{tabular}

M. :Monacha cantiana C.: Cochlecilla acuta T.: Theba pisana 
Table 3. Population dynamics of land snail species on guava and navel orange trees at Abu-Abdalla village, Sedy salem district, Kafr El-Sheikh Governorate, 2016-2017.

\begin{tabular}{lcccccccc}
\hline & \multicolumn{6}{c}{ Average numbers of snail species } \\
\cline { 2 - 9 } Months & \multicolumn{4}{c}{ Guava } & \multicolumn{4}{c}{ Orange } \\
\cline { 2 - 9 } & M & C & T & Total & M & C & T & Total \\
\hline Sep. & 10.0 & 29.0 & 7.6 & 46.6 & 12.0 & 6.6 & 29.0 & 47.6 \\
Oct. & 13.4 & 19.0 & 16.3 & 48.7 & 16.0 & 12.4 & 14.0 & 41.4 \\
Nov. & 10.4 & 6.2 & 8.4 & 25.0 & 20.0 & 4.7 & 8.0 & 32.7 \\
Dec. & - & - & - & - & - & - & - & - \\
Jan. & - & - & - & - & 8.1 & - & - & - \\
Feb. & 6.0 & - & - & 6.0 & 31.0 & - & 11.0 & 41.0 \\
Mar. & 8.0 & 19.2 & 7.2 & 34.4 & 48.2 & 20.0 & 25.0 & 93.2 \\
Apr. & 30.0 & 24.7 & 9.0 & 63.7 & 78.2 & 19.0 & 36.0 & 133.2 \\
May & 21.9 & 39.0 & 9.6 & 70.5 & 151.0 & 30.0 & 45.0 & 226.0 \\
Jun & 46.0 & 28.0 & 9.0 & 87.9 & 70.0 & 34.0 & 39.0 & 143.0 \\
Jul. & 10.0 & 24.0 & 11.0 & 45.0 & 35.0 & 31.0 & 20.0 & 86.0 \\
Aug. & 9.4 & 30.0 & 8.5 & 47.9 & 20.0 & 24.0 & 27.0 & 71.0 \\
\hline Total & 156.1 & 219.7 & 77.6 & 478.7 & 449.5 & 181.7 & 203.0 & 915.1 \\
\hline Mean & 13.8 & 18.3 & 6.5 & 39.9 & 40.8 & 15.1 & 17.9 & 76.3 \\
\hline M.: Monacha cantiana & C.: Cochlecilla acuta & T.: Theba pisana
\end{tabular}

Data in Table (4) showed the fluctuation on the economic fruit orchard at Salait village, Qullen district during 2015-2016 season. Data indicated that $M$. cantiana was the predominant species on all fruit orchard and existent in high number during different months.

The two land snail species $M$. cantiana and $C$. acuta found on guava trees with high numbers during spring and summer seasons. The results showed that the number of $M$. cantiana fluctuated between 4.7 and 131.6 individuals/tree during October 2015 and April 2016, respectively. C. acuta snails were recorded 45.0, 125.0 and 140.6 individuals /tree during March, April and May 2016, respectively. Ismail et al. (2011) reported that $M$. cartusiana snail was recorded with high density during spring months (March, April and May) as compared with winter on Egyptian clover, wheat, broad bean, navel orange and chicory. Maha, and Awad (2008) recorded that the highest figures of the population density of the tested snails and slugs was observed during April and May due to the suitable climatic conditions (temperature 18.7 to $20.6{ }^{0} \mathrm{C} \&$ relative humidity $50.7-51.3 \%$ ). Numbers of snails varied according to the year season whereas guava trees recorded the highest number of snails during spring months, its population values increased from 6.8 in January 2016 to 260.2 individuals /tree in April 2016. On the other hand, orange trees were highly infested with different snail species during the first season. $M$. cantiana infestation recorded 90.7 individuals/tree during April 2016, while C. acuta infestation recorded 27.4 individuals/tree during May2016. Also, T. pisana was recorded 30.3 and 24.6 individuals/tree during April and July 2016, respectively. The highest population of $M$. cantiana on orange trees was throughout the first year, whereas population densities ranged between 8.2 in September 2015 to 90.7 individuals /tree with total number 266.9 snails.
Table 4. Population dynamics of land snail species on guava and navel orange trees at Salait village, Quallen district, Kafr El-Sheikh Governorate 2015-2016.

\begin{tabular}{lcccccccc}
\hline & \multicolumn{6}{c}{ Average number of snail species } \\
\cline { 2 - 9 } Months & \multicolumn{4}{c}{ Guava } & \multicolumn{5}{c}{ Orange } \\
\cline { 2 - 9 } & M & C & T & Total & M & C & T & Total \\
\hline Sep. & 6.0 & 5.2 & - & 11.2 & 8,2 & 8.1 & 5.3 & 21.6 \\
Oct. & 4.7 & 7.4 & - & 12.1 & - & 6.0 & 1.9 & 4.9 \\
Nov. & - & - & - & - & - & - & - & - \\
Dec. & - & - & - & - & - & - & - & - \\
Jan. & 5.2 & - & - & 6.8 & 5.2 & - & - & 5.2 \\
Feb. & 68.1 & 18.2 & - & 86.3 & 7.0 & 5.3 & 5.0 & 17.3 \\
Mar. & 98.0 & 45.0 & - & 143.0 & 24.8 & 12.2 & 11.0 & 48.0 \\
Apr. & 131.6 & 125.0 & - & 260.2 & 90.7 & 18.5 & 30.3 & 139.5 \\
May & 90.4 & 140.6 & - & 230.0 & 63.0 & 27.4 & 12.2 & 102.6 \\
Jun. & 128.4 & 35.0 & - & 163.4 & 29.0 & 13.0 & 18.4 & 60.4 \\
Jul. & 89.0 & 24.0 & - & 113.0 & 24.0 & 19.0 & 24.6 & 67.6 \\
Aug. & 126.0 & 81.2 & - & 207.2 & 15.0 & 15.1 & 14.3 & 44.4 \\
\hline Total & 747.4 & 481.6 & - & 1233.0 & 266.9 & 124.6 & 123.0 & 511.5 \\
\hline Mean & 62.3 & 40.1 & - & 102.8 & 22.2 & 10.4 & 10.3 & 42.6 \\
\hline M.: Monacha cantiana & C.: Cochlecilla acuta & T.: Theba pisana
\end{tabular}

Data in Table (5) indicated that M. cantiana, $C$. acuta and $T$. pisana species were recorded during 20162017 season in the same district, C. acuta was recorded the highest population during April, 2017(320.0) individuals/ tree followed by $M$. cantiana which was recorded 258.4 snails /tree during May., 2017; while T. pisana was recorded 36.0 snails /tree during April, 2017. The lowest populations for the previous species was recorded 9.7, 3.5 and 2.3 snail /tree, respectively during October,2016 and January,2017. On the other hand, orange trees were highly infested with different snail species during the second season. M. cantiana infestation was 123 .1individuals / tree during June., 2017.The highest infestation with $M$. cantiana on orange trees was throughout the year ranged between 5.3 and 123.1individuals/tree in February and June,2017, respectively with total number of 590.4 snails. There was one peak during June 2017. A similar result was obtained by Sharshir et al (1996). On the other hand, $C$. acuta was recorded the highest number 68.0 snails during April, 2017 and the lowest number was 12.0 snails during February,2017 and the total number was 319.3 snails during the whole season, while $T$. pisana snails were recorded the highest number 14.2 snails during April and the lowest number was 5.2 snail during October, 2016 and the total number was 91.9 snails during 2016-2017season.

The highest number of land snail on guava orchard (501.0) during April and the lowest number (5.8) during January in the second season. Meanwhile the highest number of land snail (180.4) during April and the lowest number (23.3) during February, on navel orange in the same season at Salait village, Quallen district.

Estimation of damage caused by certain land snails to guava and navel orange trees:

Damage caused by $M$. cantiana to guava and orange leaves was estimated under field condition. Data in table (6) showed that $M$. cantiana snails caused damaged with $13.7 \%$ to navel orange leaves since the total leaves area was $23.21 \mathrm{Cm}^{2}$ and the damaged area was $3.19 \mathrm{Cm}^{2}$. 
Damage in guava leaves harbored less percentage with 10.4 since the total studied leaf area was $31.78 \mathrm{Cm}^{2}$ and the damaged area was $3.29 \mathrm{Cm}^{2}$. These results agreed with Zedan et al. (2005) who reported that the land snails Eobania vermiculata and Cepaea nemoralis caused damage to leaves of orange and guava with 19.7 and $9.6 \%$ respectively. Asran et al. (2011) cleared that the lowest damage to navel orange was recorded in March with $0.64 \%$ while the highest damage observed in May with $19 \%$.

Table 5. Population dynamics of land snail species on guava and navel orange trees at Salait village, Quallen district, KafrEl- Sheikh Governorate 2016-2017 season.

\begin{tabular}{lcccccccc}
\hline & \multicolumn{6}{c}{ Average number of snail species } \\
\cline { 2 - 9 } Months & \multicolumn{4}{c}{ Guava } & \multicolumn{5}{c}{ Orange } \\
\cline { 2 - 9 } & $\mathbf{M}$ & $\mathbf{C}$ & $\mathbf{T}$ & Total & M & C & T & Total \\
\hline Sep. & 12.0 & 12.7 & 9.0 & 33.7 & 12.0 & 28.0 & 8.3 & 48.2 \\
Oct. & 5.3 & 9.7 & 7.3 & 22.3 & 8.1 & 24.0 & 5.2 & 37.3 \\
Nov. & - & - & - & - & - & - & - & - \\
Dec. & - & - & - & - & - & - & - & - \\
Jan. & 3.5 & - & 2.3 & 5.8 & - & - & - & - \\
Feb. & 9.0 & 60.2 & 8.3 & 77.5 & 5.3 & 12.0 & 6.0 & 23.3 \\
Mar. & 81.0 & 119.0 & 120.4 & 327.0 & 76.0 & 36.0 & 10.0 & 122.6 \\
Apr. & 145.0 & 320.0 & 36.0 & 501.0 & 97.6 & 68.0 & 14.2 & 180.4 \\
May & 258.4 & 130.0 & 22.0 & 410.4 & 80.0 & 59.0 & 12.3 & 151.3 \\
Jun. & 217.0 & 118.0 & 14.0 & 349.0 & 123.1 & 40.1 & 10.8 & 174.0 \\
Jul. & 85.2 & 224.0 & 10.0 & 319.2 & 85.3 & 30.0 & 7.0 & 122.3 \\
Aug. & 114.4 & 90.0 & 5.0 & 209.4 & 103.0 & 21.6 & 5.8 & 130.4 \\
\hline Total & 930.0 & 1063.9 & 335.9 & 2329.5 & 590.4 & 319.3 & 91.9 & 989.0 \\
\hline Mean & 77.5 & 886.3 & 28.0 & 194.0 & 49.0 & 26.6 & 7.7 & 82.5 \\
\hline M.: Monacha cantiana & C.: Cochlecilla acuta & T.: Theba pisana
\end{tabular}

Table 6. Damage caused by Monacha cantiana to two orchards, Navel orange and Guava orchards.

\begin{tabular}{lcccc}
\hline $\begin{array}{c}\text { Snail } \\
\text { species }\end{array}$ & $\begin{array}{c}\text { Crop } \\
\text { parts }\end{array}$ & $\begin{array}{c}\text { Total leaf } \\
\text { area }\end{array}$ & $\begin{array}{c}\text { Damaged } \\
\text { area }\end{array}$ & $\begin{array}{c}\text { Damage } \\
\text { \% }\end{array}$ \\
\hline Monacha & Orange leaves & 23.21 & 3.19 & 13.7 \\
cantiana & Guava leaves & 31.78 & 3.29 & 10.4 \\
\hline
\end{tabular}

\section{REFERENCES}

Asran, A.A., M.S. Keshta, M. M. Mortada and Fatma K. Khidr (2011): Influence of climatic factor on population density of land snails infesting some crops and their damage J.plant prot. And pathology, Mansoura Univ., Vol. 2(4): 501 - 508, 2011.
El-Deeb, H.I.; Asran, A.A. and Kuehnert, G. (1985): Damage and losses caused by rodent to mandarin and certain varieties of orange. J. Agric. Mansoura, 10 (12):564-566.

Godan, D: (1983). Pest slugs and snails (Biology and control). Springer Verlag, Berlin, Meidelberg, New York, 1-991.

Hashem, A. G.; Nakhla, J. M., Tadros, A.W. and Korashy, M. A. (1993): Monitoring land snails on sweet orange trees in Behera Governorate (Egypt). Zagazig J. Agric. Res. Vol. 20 No. (2 A): 691-698.

Ismail, Sh. A.A.; Shetaia, S. Z. S.; Arafa, A.I. and Abd-elAtty, S.F (2011): Incidence and seasonal fluctuation of certain land Gastropod species associated with some crops and weeds at Sharkia Governorate. J. Plant Prot. Res. And Path., Mansoura Univ., Vol. 2 (12): 1103- 2011.

Mohamed, M.F. (1994): Ecological, biological and toxicological studies on land snails. M.Sc thesis, Fac. Agric. Cairo Univ.

Maha, F. M. and Awad, M.H.M. (2008): Population density of certain land snail and slug species and their damage to some fields and vegetable crops. Egypt. J. Agric. Res., 86 (5): 1763- 1772.

Mahrous, M.E.; Ibrahim, M.H. and Abd-Elaal, E. M. (2002) :Control of certain land snails under field conditions in Sharkia Governorate. Egyptian J. of Agric. Res. 29:1041-1045.

Nadia, M. Edrese and E.A.Refaei (2018):Sensitivity of four land snail species to spinosad biocide as a biotic and contact application. Egy.J.plant pro. Res. 6(2): $1-9$.

Shahawy, W.A. (1998): Ecological studies and some control methods for land snails Monacha cantiana (Montagu) at Kafr EL- Sheikh Governorate. M.Sc thesis Fac. Agric. Tanta Univ., 86 pp.

Sharshir, F.A., Okka, M. A. and Helal, R. M. Y. (1996): Non - target soil organisms and predacious mites associated with the land snail Monacha sp. (Muller) in Kafr-elsheikh. J.Agric. Res., Tanta Univ. 22 (3): 407-416.

Zidan, H.A., M.M. Mortada and M.H, Awad(2005) :Survey, damage and losses caused by land snails on certain crops at Dakahlia.Shrkia and Domietta Governorates. Egypt J.Agric., 83(2). 669-677.

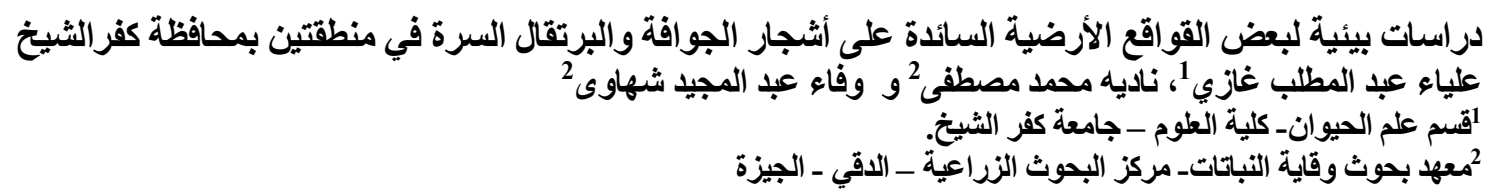

أجرى هذا البحث في مركزي سبدي سالم وقلين بمحافظة كفر الثيخ خلال موسمي

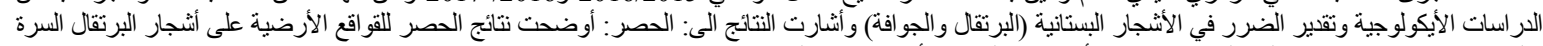

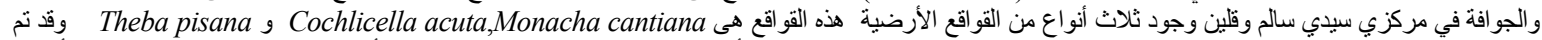

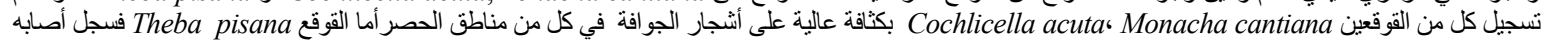

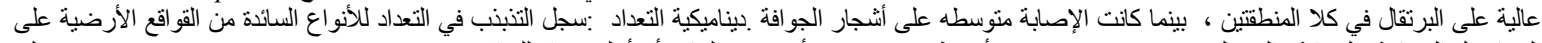

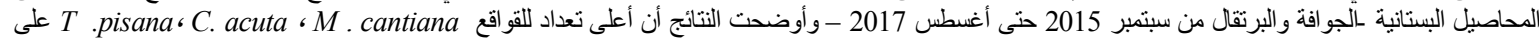

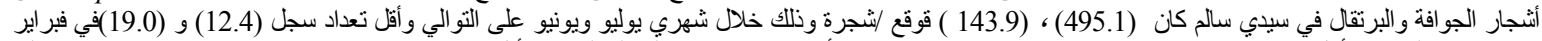

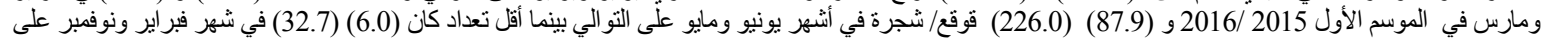

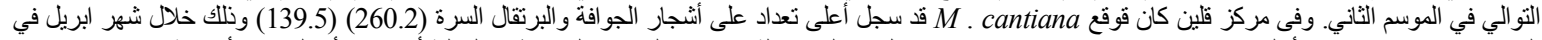

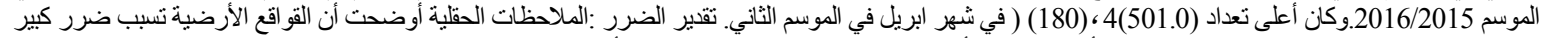

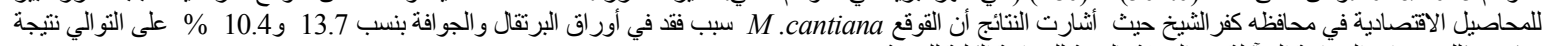

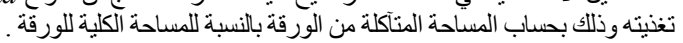

